\title{
PELATIHAN PEMBUATAN ES KRIM SEHAT UNTUK BALITA \\ BAGI KADER POSYANDU DI KELURAHAN DUREN SAWIT JAKARTA TIMUR
}

\author{
Ridawati $^{1)}$, Alsuhendra ${ }^{2)}$ \\ Jurusan IKK, Fakultas Teknik, Universitas Negeri Jakarta
}

\begin{abstract}
ABSTRAK
Es krim merupakan produk olahan susu yang dibuat dengan cara membekukan dan mencampur bahan baku secara bersama-sama. Bahan yang digunakan adalah kombinasi susu dengan bahan tambahan seperti gula dan madu atau tanpa bahan perasa dan warna, dan stabilizer. Kegiatan pengabdian kepada masyarakat ini bertujuan untuk meningkatkan pengetahuan dan ketrampilan kader posyandu tentang mengolah es krim dan produk olahannya seperti milkshake menjadi salah satu minuman sehat yang disukai oleh anak-anak. Kegiatan ini dilaksanakan di TK Ruhul Islam Kelurahan Duren Sawit, dengan melibatkan 20 orang peserta. Hasil dari pelaksanaan pengabdian ini terjadi peningkatan pengetahuan dan ketrampilan kader posyandu tentang es krim sehat dan produk olahannya seperti milkshake.
\end{abstract}

Kata Kunci : Eskrim, posyandu

\section{PENDAHULUAN}

Kecamatan Duren Sawit merupakan salah satu kecamatan di Wilayah Jakarta Timur yang terletak pada jantung kota Jakarta Timur. Kecamatan Duren Sawit pada awalnya merupakan salah satu kelurahan yang terdapat di dalam wilayah Kecamatan Jatinegara, yaitu kelurahan Duren Sawit. Dikarenakan wilayah cakupannya yang sangat luas dan dilakukannya pemekaran daerah kota maka pada tahun 1990-an dibentuk Kecamatan Duren Sawit.

Kecamatan Duren Sawit yang terdiri dari 7 kelurahan diantaranya Kelurahan Duren Sawit. Kecamatan ini berbatasan dengan Kecamatan Cakung di sebelah utara, Kecamatan Jatinegara di sebelah barat, Kecamatan Bekasi Barat di sebelah timur, dan KecamatanMakasar di sebelah selatan. Kecamatan Duren Sawit dibagi menjadi tujuh kelurahan yaitu Kelurahan Pondok Bambu, Duren Sawit, Pondok Kelapa, Pondok Kopi, Malaka Jaya, Malaka Sari dan Kelurahan Klender Klender. Kecamatan Duren Sawit terdiri dari 95 Rukun Warga dan 1.103 Rukun Tetangga dengan luas wilayah 22,8 $\mathrm{km}^{2}$, merupakan kecamatan yang memiliki ukuran luas urutan nomor tiga terbesar di Jakarta Timur, setelah Kecamatan Cipayung dan Pulo Gadung. Wilayah dengan jumlah KK 82.164 dan jumlah penduduk 346.197 total jiwa serta jumlah penduduk miskin sebanyak 4.590 jiwa. (Sumber : Kantor Statistik Jakarta Timur bulan Desember 2000 dalam Suku Dinas Kebersihan Jakarta Timur 2002). Sebagian besar penduduk Kecamatan Duren Sawit adalah pendatang, sedangkan sebagian kecilnya adalah penduduk asli yang keberadaannya mulai tergeser. Pembangunan Banjir Kanal Timur (BKT) juga menyebabkan semakin tergusurnya penduduk asli Kecamatan Duren Sawit, khususnya penduduk yang tinggal di sekitar BKT tersebut.

Es krim merupakan salah satu produk olahan susu yang digemari masyarakat Indonesia khususnya anak-anak. Es krim memiliki rasa yang lezat, manis, dan nikmat apalagi jika dihidangkan saat cuaca sedang panas. Terutama anak-anak yang selalu dapat mendapatkan produk es krim di sekitar tempat tinggal mereka, sehingga beberapa orangtua khawatir akan kebiasaan anak-anak untuk mengkonsumsi es krim yang dapat diperoleh dengan mudah tersebut. Salah satu hal yang dikhawatirkan adalah produk kurang higienis dan bahan-bahan pembuat es krim yang tidak memenuhi persyaratan sebagai bahan yang aman untuk dikonsumsi.

Es krim dapat diolah lebih lanjut menjadi produk minuman seperti Milkshake. Milkshake menjadi salah satu jenis minuman yang sangat disukai. Selain memberikan rasa yang segar dan 
enak, juga manfaatnya untuk kesehatan. Milkshake adalah minuman yang dibuat dari campuran susu cair es krim, buah, pemanis, sirup buah atau saus cokelat, disajikan dingin dengan topping whipped cream. Cara pembuatan menggunakan shaker (sejenis gelas berpenutup, kemudian semua bahan dimasukkan dalam shaker dan dikocok agar semua bahan tercampur) atau di blender. Dibandingkan dengan jenis minuman ringan lainnya seperti soda, milkshake memang mengandung beberapa komponen yang memberikan manfaat kesehatan bagi tubuh. seperti protein, serat, vitamin dan mineral. Es krim dan susu menjadi bahan utama dari milkshake, dan seperti yang diketahui susu mengandung protein yang baik untuk kesehatan. Bagi orang yang kurang menyukai aroma susu, mungkin milkshake bisa menjadi pilihan untuk menggantikannya. Konsumsi segelas susu perhari membantu kesehatan tulang secara optimal. Buah yang digunakan dalam pembuatan milkshake memberi sumbangan terhadap kebutuhan serat harian. Jumlah serat pada milkshake bergantung dari jenis dan jumlah buah yang digunakan. Serat berfungsi menjaga kesehatan saluran cerna dan memberikan rasa kenyang lebih lama. Sumber vitamin dan mineral pada milkshake berasal dari buah yang digunakan. Biasanya vitamin yang terdapat dari milkshake antara lain bitamin A, Vitamin C, vitamin $\mathrm{E}$, kalsium, mangan, kalium.

Buah yang digunakan dalam pembuatan milkshake adalah buah dapat memberikan rasa manis yang alami, sehingga tidak perlu lagi menambahkan gula, sirup buah, atau pemanis lainnya. Susu dan es krim yang digunakan adalah es krim dengan rasa yang sesuai dengan buah yang digunakan. Penambahan topping pada milkshake sebaiknya berupa irisan buah/ cokelat, sukade atau manisan buah lainnya.

\section{B. Permasalahan Mitra}

Pergantian pimpinan, terpuruknya nilai tukar rupiah yang melanda Indonesia berdampak terhadap gizi anak-anak, meningkatnya angka kesakitan dan kematian. Terjadinya peningkatan penyebaran penyakit infeksi turut mempengaruhi keadaan gizi penderita serta turut mempengaruhi aktivitas kegiatan masyarakat.
Berdasarkan latar belakang diatas, dirumuskan beberapa permasalahan sebagai berikut :

1. Bagaimanakah cara mengolah es krim dan produk olahannya seperti milkshake menjadi salah satu minuman sehat yang disukai oleh anak-anak?

2. Bagaimanakah cara meningkatkan pengetahuan masyarakan akan pentingnya protein sebagai salah satu zat gizi yang dibutuhkan oleh anak-anak dan balita?

Salah satu dharma perguruan tinggi adalah pengabdian pada masyarakat, hal ini mengisyaratkan bahwa tugas perguruan tinggi antara lain adalah melaksanakan pengabdian kepada masyarakat dengan seoptimal mungkin. Program pengabdian pada masyarakat dilaksanakan dengan cara memanfaatkan dan menerapkan hasil penelitian maupun hasil pendidikan perguruan tinggi. Pengabdian pada masyarakat dapat dilakukan dalam bentuk pendidikan dan pelatihan kepada masyarakat. Program pengabdian pada masyarakat dilaksanakan dengan menganut asas kelembagaan, asas ilmu amaliah, dan amal ilmiah, asas kerjasama, asas kesinambungan, serta asas edukatif dan pengembangan. Khalayak sasaran kegiatan pengabdian kepada masyarakat adalah masyarakat di luar kampus yang merupakan mitra kerja perguruan tinggi untuk menerapkan Ipteks dalam rangka menyelesaikan masalah yang dihadapinya.

\section{TINJAUAN PUSTAKA}

\section{A. Es Krim}

Es krim adalah sebuah makanan beku dibuat dari produk susu seperti krim (atau sejenisnya), digabungkan dengan perasa dan pemanis. Campuran ini didinginkan dengan mengaduk sambil mengurangi suhunya untuk mencegah pembentukan kristal es besar. Tradisionalnya, suhu dikurangi dengan menaruh campuran es krim ke sebuah wadah dimasukkan ke dalam campuran es pecah dan garam. Garam membuat air cair dapat berada di bawah titik 
beku air murni, membuat wadah tersebut mendapat sentuhan merata dengan air dan es tersebut.

Meskipun istilah es krim sering digunakan untuk menunjuk ke "dessert" beku dan makanan ringan, tapi sebenarnya digunakan unuk menunjuk ke "dessert" beku dan makanan ringan yang terdiri dari lemak susu. Banyak negara, termasuk Amerika Serikat, membatasi penggunaan istilah tersebut berdasarkan kuantitas dari bahan dasar makanan tersebut

Es krim merupakan produk olahan susu yang dibuat dengan cara membekukan dan mencampur bahan baku secara bersama-sama. Bahan yang digunakan adalah kombinasi susu dengan bahan tambahan seperti gula dan madu atau tanpa bahan perasa dan warna, dan stabilizer, bahan campuran es krim disebut ice cream mix dengan pencampuran bahan yang tepat dan pengolahan yang benar maka dapat dihasilkan es krim dengan kualitas baik. Nilai gizi es krim sangat tergantung pada nilai gizi bahan baku yang digunakan, untuk membuat es krim yang memiliki kualitas tinggi bahan bakunya perlu diketahui dengan pasti, dengan menggunakan susu sebagai bahan utama pembuatan es krim maka es krim memiliki sumbangan terbesar nilai gizinya. Dibalik kelembutan dan rasa manisnya, es krim terbukti memiliki beberapa fakta gizi yang tidak terduga, keunggulan es krim yang didukung oleh bahanutamanya yaitu susu tanpa lemak dan lemak susu maka es krim hampir sempurna dengan kandungan gizi yang lengkap. Banyak tersedia bahan es krim yang mudah dalam pembuatannya, yaitu es krim instan, dengan adanya es krim yang mudah dan praktis konsumsi es krim di Indonesia mulai meningkat secara sering dengan adanya es krim instan yang pemuatannya tidak memerlukan ahli khusus dan dapat dibuat di rumah. Pembuatan es krim menggunakan bahan tambahan yaitu bahan pengembang dan bahan penstabil. Untuk bahan pengembang dapat digunakan baking powder (sodium bikarbonat) yang merupakan bahan pengembang dan dipakai untuk meningkatkan volume dan memperingan tekstur bahan makanan antara lain es krim. Fungsi lain bahan pengembang jika ditambahan dengan adonan es krim karena sodium bikarbonat bereaksi dengan asam juga digunakan sebagai obat untuk menetralkan asam lambung berlebihan. Bahan penstabil (stabilizer) merupakan bahan aditif yang ditambahkan dalam jumlah kecil untuk mempertahankan emulsi sekaligus memperbaiki kelembutan produk es krim, mencegah pembentukan kristal es yang besar pada es krim, memberikan keseragaman produk, memberikan ketahanan agar tidak meleleh atau mencair dan memperbaiki sifat produk. Es krim yang diperoleh dengan penambahan bahan penstabil menjadi menjadi lebih halus dan lembut. Tekstur lembut es krim juga dapat diperoleh melalui proses pembekuan cepat yang akan menghasilkan kristal es berukuran kecil dan halus serta tekstur es krim lembut. Pembuatan es krim mempunyai prinsip yaitu dapat membentuk rongga udara pada ice cream mix, sehingga diperoleh pengembangan volume es krim agar menjadikan es krim lebih ringan dan tidak padat serta mempunyai tekstur yang lembut, oleh karena itu es krim merupakan produk olahan susu yang disukai masyarakat.

\section{B. Milk Shake}

Bahan dasar milkshake hampir sama dengan smoothie, yaitu buah, sayuran, sirup gula, susu tawar cair atau kental, dan potongan es batu. Bahan milkshake yang membedakannya dengan smoothie adalah susu dan es krim yang selalu melengkapi setiap penampilan milkshake.

Proses pembuatan milkshake. Ada dua cara membuat milkshake, yaitu diblender dan juga dengan menggunakan shaker. Masukkan sari buah, sirup gula, susu tawar cair, potongan es batu ke dalam tabung shaker. Kocok hingga semua bahan tercampur rata. Tuang milkshake ke dalam gelas, dan sajikan bersama es krim sebagai topping di atas milkshake. Anda juga bisa mencampur es krim bersama bahan ke dalam tabung shaker sebagai variasi sajian milkshake.

\section{Protein}

Status gizi pada anak menentukan pembangunan nasioanal karena anak merupakan generasi yang akan melanjutkan pembangunan ini. Kalau status gizi anak tidak baik, ini akan berpengaruh terhadap kondisi fisik dan 
psikologis pada anak tersebut. Masalah gizi pada anak sering seperti masalah gizi buruk (marasmus maupun kwasiorkor), gizi kurang (kekurangan zat mikro maupun makro) maupun gizi lebih (obesitas) merupakan masalah nasional yang memerlukan penganganan secara terpadu oleh seluruh unsur masyarakat. Salah satu zat gizi yang sangat dibutuhkan pada masa pertumbuhan seorang anak adalah protein. Protein memiliki fungsi :

“ Pertumbuhan jaringan baru

“ Metabolisme untuk energi

“ Metabolisme ke dalam zat-zat vital dalam fungsi tubuh

“ Enzim-enzim yang esensial bagi fungsi tubuh yang normal

“ Hormon-hormon tertentu

Protein dapat digolongkan sebagai protein yaitu golongan yang termasuk protein-protein yang pada hidrolisis menghasilkan hanya asam amino atau derivatnya. Contohnya albumin, globulin, glutelin, protein yang larut dalam alkohol, albuminoid dan protamin. Selain protein sederhana, ada juga protein gabungan, seperti nucleoprotein, glikoprotein dan fosfoprotein. Nukleoprotein, adalah gabungan dari satu atau lebih molekul protein dengan asam nukleat. Glikoprotein, gabungan dari molekul protein dan zat yang mengandung gugusan karbohidrat selain asam nukleat, misalnya mucin, Fosfoprotein, gabungan molekul protein dengan zat yang mengandung fosfor selain asam nukleat atau lesitin, misalnya kasein.

Protein terdiri dari asam-asam amino esensial dan asam amino non esensial. Asam amino esensial merupakan asam amino yang tidak dihasilkan oleh tubuh, sehingga harus dikonsumsi dari bahan makanan, sedangkan asam amino non esensial dapat dihasilkan dalam proses metabolism di dalam tubuh manusia. Asam amino terdiri atas gugusan amino yang mengandung amonia dan gugusan karbonhidrogen yang dibangun dengan kombinasi asam-asam lemak. Tiga (3) kelompok, yaitu :

1) Asam amino esensial (tidak dapat disintesis oleh tubuh), meliputi: valin, arginin, leusin, isoleusin, fenilalanin, triptofan, metionin, lisin, treonin, dan histidin (arginin dan histidin esensial untuk bayi, tetapi tidak bagi orang dewasa).

2) Asam amino semi esensial, meliputi: glisin, serin, sistin, dan tirosin.

3) Asam amino non esensial (dapat disintesis oleh tubuh), meliputi: alanin, prolin, serin, sistein, tirosin, asparagin, glutamin, asam aspartat, dan asam glutamate.

Di dalam tubuh protein memainkan peranan penting sebagai zat pembangun tubuh, zat pengatur di dalam tubuh, dan sebagai sumber energi. Sebagai zat pembangun, protein berperan membentuk jaringan baru, misalnya membentuk janin pada masa kehamilan atau jaringan baru pada proses pertumbuhan anak. Protein juga penting untuk memelihara jaringan yang telah ada atau mengganti bagian-bagian yang aus atau rusak.

Fungsi protein sebagai sumber energi tidak begitu utama dibandingkan dengan karbohidrat dan lemak. Dalam keadaan normal, tubuh lebih menggunakan protein sebagai zat pembangun dan pengatur daripada sebagai sumber energi. Namun, apabila tubuh sedang kekurangan energi, maka protein ini terpaksa dipakai sebagai sumber energi. Untuk setiap gram protein dapat dihasilkan energi sekitar $4 \mathrm{Kal} / \mathrm{g}$, atau setara dengan kandungan energi karbohidrat.

Secara lebih rinci peranan utama protein di dalam tubuh dapat diringkaskan menjadi 6, yaitu untuk :

1. pertumbuhan dan pemeliharaan jaringan

2. pembentukan senyawa tubuh yang esensial, seperti enzim, hormon, hemoglobin, neurotransmitter (misalnya serotonin), dan senyawa yang terlibat dalam pembekuan darah

3. pengaturan/regulasi keseimbangan air

4. mempertahankan netralitas tubuh melalui fungsinya sebagai senyawa penyangga (buffer)

5. membentuk antibodi

6. transfer zat gizi

Pemecahan atau hidrolisis protein akan menghasilkan asam-asam amino penyusunnya. 
Proses hidrolisa dapat dilakukan antara lain menggunakan larutan $\mathrm{HCl}$ atau $\mathrm{H}_{2} \mathrm{SO}_{4}$ 6-8 $\mathrm{N}$ selama 12-48 jam. Hidrolisis protein dengan asam akan menghasilkan asam-asam amino yang memiliki sifat optis aktif yang tetap (bentuk L) seperti terdapatnya di alam. Hidrolisis dapat pula dilakukan dengan menggunakan alkali, misalnya $\mathrm{BaOH}$.

Jika unsur-unsur protein murni dianalisis, maka komposisi unsur-unsur penyusun yang umum dijumpai adalah C (50-55\%), O (20-25\%),

$\mathrm{P}, \mathrm{Fe}$, dan $\mathrm{Cu}$ dalam jumlah sedikit. Di alam umumnya terdapat 20 jenis asam amino (bahkan untuk protein tertentu dapat 25 jenis), sehingga jenis protein yang dapat dibentuk dari ratusan atau bahkan ribuan unit asam-asam amino berbeda-beda secara matematis adalah tak terhingga.

Protein dapat dikelompokkan berdasar-kan beberapa kriteria. Berdasarkan sumbernya protein dapat dibagi menjadi dua, yaitu protein asal tanaman (protein nabati) dan protein asal hewan (protein hewani). Sumber utama dari protein nabati adalah kacang-kacangan, sedangkan protein hewani banyak ditemukan pada telur, ikan, daging, dan susu.

Setidaknya ada 10 jenis protein jika dikelompokkan menurut perannya dalam makhluk hidup. Berbagai jenis protein tersebut adalah sebagai berikut :

1) Protein di dalam plasma darah, cairan limfa, dan cairan tubuh lain. Protein ini berperan sebagai bahan yang mengatur tekanan osmosis cairan tubuh. Protein ini juga dapat bertindak sebagai penyangga atau buffer, sehingga dapat menjaga kestabilan $\mathrm{pH}$ cairan tubuh. Peran lain dari protein dalam kelompok ini adalah sebagai pembawa asam amino yang perlu dipindahkan dari satu organ ke organ yang lain. Beberapa protein yang larut dalam serum cairan tubuh adalah enzim, sedangkan yang lain berperan sebagai senyawa antibodi yang melindungi tubuh dari serangan mikroorganisme penyebab penyakit dan benda asing lain.

2) Protein kontraksi. Protein ini terdapat dalam jaringan otot dan sel kontraksi hewan tingkat rendah. Contoh protein di dalam otot adalah aktin yang dalam keadaan konstraksi akan terikat dengan protein myosin menjadi aktomyosin.

3) Protein pernafasan. Protein ini berperan mengangkut oksigen dari organ pernafasan ke jaringan yang memer-lukan oksigen, seperti hemoglobin.

4) Enzim. Enzim merupakan senyawa yang terbuat dari protein untuk mempercepat (mengkatalisis) reaksi-reaksi metabolisme dalam makhluk hidrup. Beberapa enzim memerlukan bahan lain non protein dengan berat molekul rendah untuk mengkatalisis reaksi, seperti vitamin dan

5) Hormon. Hormon merupakan jenis protein yang diproduksi oleh kelenjarkelenjar endoktrin dan kemudian diangkut oleh darah ke organ tubuh.

6) Protein cadangan. Jaringan hewan dan tanaman memiliki protein tertentu yang disimpan sebagai cadangan makanan pada lembaga, biji, janin yang baru dilahirkan, telur, atau susu.

7) Protein inti sel. Protein inti sel atau nukleoprotein adalah jenis protein yang berperan penting dalam proses pewarisan sifat-sifat keturunan yang terdapat dalam kromosom.

8) Protein musin dan mukoid. Musin dan mukoid adalah kelompok protein sangat kental yang menyusun cairan tubuh. Protein ini dapat ditemukan dalam saliva, cairan pencernaan, pankreas dan usus, cairan kental pada persendian, cairan tali pusar dan organ-organ lain yang memiliki kekentalan serupa. Umumnya protein ini merupakan gabungan antara protein dan polisakarida.

9) Kolagen. Kolagen adalah kelompok protein dalam jaringan pengikat, misalnya dalam tulang, tulang rawan, urat ligamen otot, dan kulit. Kolagen tidak ditemukan dalam tanaman.

10) Keratin. Keratin bersifat tidak larut dalam air dan sulit dihidrolisis, misalnya dalam rambut, tanduk, kulit, terapak kaki hewan, dan kuku. Protein ini tidak terdapat dalam tanaman.

Di samping berdasarkan peranannya dalam tubuh, protein dapat pula diklasifikasikan menurut sifat fisik dan kimia, khususnya berdasarkan kelarutannya. Secara umum, jenis protein sederhana yang diklasifikasikan berdasarkan kelarutannya adalah sebagai berikut : 
1. Albumin, yaitu protein yang dapat larut dalam air dan terkoagulasi oleh panas. Contohnya adalah albumin telur, albumin serum darah, dan laktalbumin dalam susu.

2. Globulin, yaitu protein yang tidak larut dalam air, larut dalam larutan garam encer, mengendap dalam larutan garam dengan konsentrasi tinggi (salting out), dan terkoagulasi oleh panas. Contohnya adalah miosinogen dalam otot, ovalbumin dalam kuning telur, dan legumin dalam kacangkacangan.

3. Prolamin (Gliadin), yaitu protein yang larut dalam etanol $70-80 \%$, tetapi tidak larut dalam air, larutan garam ataupun etanol absolut/murni. Contohnya adalah gliadin dalam gandum, zein dalam jagung, dan hordain dalam barley.

4. Glutelin, yaitu protein yang tidak larut dalam pelarut netral, larutan garam atau etanol, tetapi dapat larut dalam larutan alkali atau asam encer. Contohnya adalah glutelin dalam gandum dan orizenin dalam beras.

5. Histon, yaitu protein yang larut dalam air dan larutan garam, tidak larut dalam amonia encer, tetapi histon yang terkoagulasi oleh panas dapat larut dalam larutan asam encer. Contohnya adalah globin dalam hemoglobin.

6. Protamin, yaitu protein yang larut dalam etanol 70-80\%, tidak larut dalam air dan etanol absolut, serta tidak terkoagulasi oleh panas. Protein ini kaya akan asam amino arginin. Contohnya adalah salmin dalam ikan salmon, klupein dalam ikan herring, dan scrombin dalam ikan mackerel.

Pengelompokkan protein berdasarkan kelarutannya dianggap cukup baik, tetapi masih terdapat beberapa kelemahan. Sebagai contoh adalah globulin, pada awalnya diartikan sebagai protein yang dapat diendapkan (salted-out) oleh larutan 50\% amonium sulfat dan dikelompokkan sebagai protein yang tak dapat larut dalam air, tetapi banyak jenis globulin serum darah yang ditunjukkan dengan cara elektroforesis, dapat larut dalam air. Karena itu, lebih praktis mengelompokkan jenis-jenis protein sederhana menjadi protein yang larut dan yang tidak larut, tanpa mengkaitkannya lagi dengan cara pengelompokkan yang lebih terperinci.

\section{MATERI DAN METODE}

Dalam kegiatan ini dilakukan proses diskusi dan pelatihan pengolahan es krim dan milkshake. Pelatihan terdiri dari beberapa tahapan yaitu :

a) Melakukan inventarisasi berbagai kegiatan yang telah dilakukan Posyandu terkait dengan Kesehatan dan Gizi

b) Melakukan pelatihan pengolahan es krim dan milkshake

c) Melakukan praktek pembuatan milkshake dari es krim dan produk olahan susu.

Mengingat jenis kegiatan ini adalah praktek dan pelatihan maka metode yang digunakan adalah :

$30 \%$ teori berupa ceramah dan diskusi kelompok

70 \% berupa demonstrasi dan praktek langsung pengolahan pembuatan milkshae dan variasinya.

\section{Tim Pelaksana :}

Universitas Negeri Jakarta (UNJ) adalah salah satu lembaga pendidikan tinggi yang berada di pusat kota Jakarta. UNJ menyelenggarakan bidang kependidikan dan non kependidikan. Salah satu Fakultas yang menyelenggarakan bidang kependidikan dan non kependidikan di UNJ adalah Fakultas Teknik. Program Studi Tata Boga merupakan salah satu program studi yang dimiliki oleh Jurusan Ilmu Kesejahteraan Keluarga (IKK). Jurusan IKK merupakan pengembangan dari Program Studi Pendidikan Kesejahteraan Keluarga (Home Economic) yang telah ada di Indonesia sejak tahun 1960 dan berada dibawah FKIP Universitas Indonesia menurut SK Dirjen DIKTI Depdikbud RI No. 112/Dikti/Kep/1984 tanggal 4 September 1984. Program Studi Pendidikan Kesejahteraan Keluarga (PKK), yang merupakan program studi setingkat sarjana (S1), memiliki 3 bidang keahlian khusus, yaitu Tata Boga, Tata Busana dan Tata Rias. Berdasarkan SK DIKTI No.269/DIKTI/ Kep/2000 pasal 6 ayat 4, Program Studi PKK berubah menjadi Jurusan 
Ilmu Kesejahteraan Keluarga (IKK) dan menggunakan Kurikulum Nasional sesuai SK MenDikBud RI No.017/U/ 1995.

Peningkatan kualitas merupakan hal yang harus terus-menerus dilakukan pada sumberdaya manusia, baik bagi staf pengajar/dosen maupun staf administrasi. Beberapa bentuk upaya peningkatan kualitas tersebut adalah pengiriman dosen untuk studi lanjut pada jenjang pendidikan yang lebih tinggi, short course, pelatihan, workshop, seminar ilmiah dan profesi skala nasional dan internasional, magang profesi, serta pengiriman staf administrasi untuk mengikuti pelatihan, workshop, atau magang profesi. Berbagai kegiatan pengabdian pada masyarakat telah dilakukan oleh staf pengajar program studi tata boga.

Pada saat ini Program Studi Tata Boga memiliki 11 orang staf pengajar tetap dengan berbagai tingkat pendidikan dan keahlian. Dari jumlah demikian, sekitar $21.1 \%$ staf pengajar memiliki jabatan akademik sebagai Lektor Kepala, 52.6\% sebagai Lektor, dan 26.3\% lainnya sebagai asisten ahli. Usia sebagian besar (68.4\%) staf pengajar berada antara 35 hingga 50 tahun, dan 21.1\% memiliki usia di bawah 35 tahun. Hanya $15.8 \%$ staf pengajar yang berusia di atas 50 tahun. Dari komposisi ini dapat dilihat bahwa sebagian besar staf pengajar masih berusia muda, yaitu usia yang potensial untuk menampilkan kinerja secara optimal.

\section{HASIL DAN PEMBAHASAN}

Minuman sehat merupakan salah satu produk olahan yang banyak digemari oleh masyarakat. Minuman sehat sering disebut juga sebagai minuman fungsional yaitu minuman yang mengandung fungsi-fungsi tambahan karena kandungan unsur penyusunnya. Salah satu minuman sehat yang disukai oleh masyarakat dari berbagai tingkat usia adalah minuman yang diolah dari susu dan produk olahannya seperti susu evaporasi, susu pasteurisasi, susu kental manis, susu asam, yoghurt dan susu bubuk. Minuman sehat yang diolah dari susu banyak mengandung protein.
Protein merupakan zat gizi yang sangat diperlukan tubuh, karena di samping berperan penting dalam pembentukan dan penggantian sel, protein juga dapat menjadi sumber energi bagi tubuh. Sebagai zat pembangun, protein menjadi bahan pembentuk jaringan-jaringan baru yang selalu terjadi dalam tubuh. Khususnya pada masa pertumbuhan, proses pembentukan jaringan terjadi secara besar-besaran, sehingga pelatihan pengolahan makanan yang mengandung protein tinggi penting dilakukan, terutama pelatihan makanan yang sering dikonsumsi oleh masyarakat, khususnya anak-anak.

Produk olahan minuman yang terbuat dari susu dikenal dengan sebutan milkshake. Milkshake diolah dari susu dengan tambahan bahan lainnya seperti buah-buahan, sayuran, susu tawar cair, sirup gula (atau gula pasir), dan juga es batu. Karakteristik dari milkshake adalah susu dan es krim yang selalu lebih dominan dibandingkan dengan bahan-bahan lainnya.

Pelatihan pembuatan milkshake ini ditujukan untuk memperkenalkan variasi produk olahan minuman lain kepada masyarakat yang memiliki nilai gizi yang tinggi yaitu mengandung protein dan dapat dikonsumsi sebagai minuman kesehatan.

Peserta pelatihan sebelumnya diminta untuk mengisi angket yang berisi pertanyaan seputar pengetahuan peserta tentang es krim, protein, sumber-sumber protein, fungsi dan peranan protein sebagai zat gizi. Angket ini merupakan evaluasi awal yang dilakukan sebelum materi pelatihan diberikan. Selanjutnya setelah pelatihan dilaksanakan, pengisiaan angket yang sama di ulang kembali oleh peserta. Angket kedua merupakan angket untuk evaluasi akhir dari kegiatan pemberian materi berupa penyuluhan oleh tim pengabdian pada masyarakat.

Penyebaran angket dan pengambilan data untuk evaluasi kegiatan penyuluhan dan pemberian materi berupa pengetahuan, sangat penting dulakukan karena peserta pelatihan adalah khalayak sasaran strategis yang diharapkan dapat menyampaikan dan menyebarluaskan pengetahuannya tentang protein sebagai sumber zat gizi. 
Persentase pengetahuan peserta tentang es krim jika dibandingkan dengan sebelum penyuluhan menunjukkan terjadi sedikit peningkatan. Sebanyak $87 \%$ peserta menyebutkan bahwa es krim merupakan salah satu produk olahan susu. Susu yang dapat digunakan sebagai bahan baku pembuatan es krim tidak hanya susu sapi. Selain itu, susu juga merupakan bahan dasar untuk produk olahan susu, seperti susu kental manis, susu bubuk, susu skim, es krim, keju, yoghurt dan susu fermentasi.

Susu kedelai merupakan ekstrak kedelai yang berbentuk seperti susu dan sering juga disebut sebagai susu kedelai. Susu kedelai dapat jiga digunakan sebagai bahan baku pembuatan es krim. Terjadi peningkatan pengetahuan masyarakat (hingga 87\%) yang menyatakan bahwa walaupun susu kedelai sering disebut dengan istilah susu, tetapi nilai gizi susu kedelai tidak sama dengan susu sapi. Kualitas protein susu sapi masih lebih baik dari pada susu kedelai.

Sebagai salah satu sumber protein, es krim tidak hanya dapat dikonsumsi langsung, tetapi juga digunakan sebagai bahan campuran untuk pembuatan minuman. Minuman yang menggunakan es krim sebagai salah satu bahan bakunya adalah milkshake. Pada awalnya hanya 62\% peserta yang mengetahui bahwa milkshake adalah produk olahan es krim. Setelah penyuluhan terjadi peningkatan persentase peserta yang menjawab benar bahwa milkshake adalah produk olahan es krim yang menyehatkan. Analisis pertanyaan angket no.1, no.4 dan no.8 (Gambar 1)

\% jawab benar pre test

q jawab benar post test

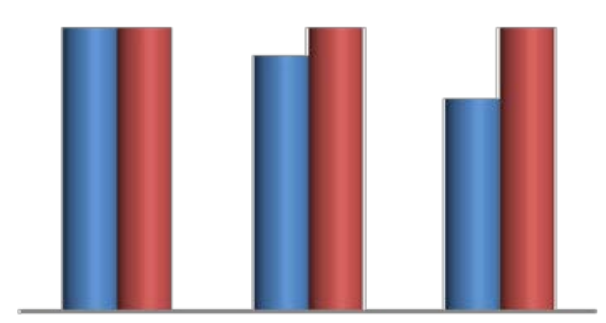

Gambar 1. Persentase Peningkatan Pengetahuan Peserta tentang Es Krim dan Milkshake
Pengetahuan peserta tentang susu sebagai salah satu sumber protein dan protein penting sebagai zat untuk pertumbuhan sebelum dan setelah penyuluhan terlihat tidak berbeda (Butir pertanyaan no. 2 dan no.5). Tetapi pengetahuan bahwa protein dapat meningkatkan daya tahan tubuh terjadi peningkatan persentase peserta yang menjawab dengan benar yaitu dari 73.9\% menjadi 87\% (Butir pertanyaan no.3, Gambar 2). Susu sebagian besar digunakan sebagai produk pangan, dipandang dari segi gizi, susu merupakan makanan yang hampir sempurna dan merupakan makanan alamiah bagi binatang menyusui yang baru lahir (Buckle et al. 1985). Susu merupakan bahan makanan yang sangat baik bermanfaat untuk kesehatan manusia, karena susu mengandung zat yang sangat diperlukan oleh tubuh seperti protein, karbohidrat, lemak, vitamin, dan mineral. Susu adalah suatu emulsi lemak dalam air, serta larutan berbagai senyawa mineral. Nilai gizi yang terdapat dalam susu sangat tinggi, karena mengandung zat-zat yang sangat dibutuhkan oleh tubuh seperti protein, lemak, karbohidrat, vitamin dan garam-garam mineral. Selain itu, susu juga mudah dicerna dan diserap oleh tubuh, hal ini menjadikan susu sebagai bahan pangan andalan dalam meningkatkan kesehatan dan gizi masyarakat (Winarno, 1992).

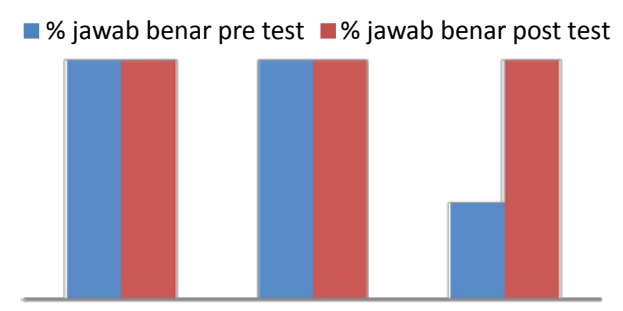

Gambar 2. Persentase Pengetahuan Peserta tentang Manfaat Susu

Selain susu sapi, susu kedelai merupakan salah satu minuman suplemen (tambahan) yang dianjurkan diminum sesuai kebutuhan. Sebagai minuman tambahan, artinya susu kedelai bukan merupakan obat, tetapi bisa menjaga kondisi tubuh agar tetap sehat sehingga tidak mudah terserang penyakit. Pada prinsipnya terdapat dua bentuk susu kedelai, yaitu susu kedelai cair dan susu kedelai bubuk. Bentuk cair jauh lebih 
banyak dibuat dan diperdagangkan. Susu kedelai dapat disajikan dalam bentuk murni, artinya tanpa penambahan gula dan cita rasa baru. Dapat juga ditambah gula atau flavor (essen/cita rasa) seperti moka, pandan, vanili, coklat, dan strawberry.

Susu kedelai dapat digunakan sebagai pengganti susu sapi terutama bagi mereka yang alergi susu sapi, yaitu yang tidak memiliki atau kurang enzim laktase dalam saluran pencernaannya, sehingga tidak mampu mencerna laktosa dalam susu sapi. Susu kedelai mampu menggantikan susu sapi karena protein susu kedelai mempunyai susunan asam amino hampir mirip dengan susu sapi. Komposisi asam amino metionin dan sistein dalam protein susu kedelai lebih sedikit daripada susu sapi. Akan tetapi, karena kandungan asam amino lisin yang cukup tinggi, maka susu kedelai dapat meningkatkan nilai gizi protein dari serealia.

Protein merupakan suatu zat makanan yang amat penting bagi tubuh, karena zat ini disamping sebagai bahan bakar dalam tubuh juga berfungsi sebagai zat pembangun dan pengatur. Protein adalah sumber asam amino yang mengandung unsur-unsur $\mathrm{C}, \mathrm{H}, \mathrm{O}$ dan $\mathrm{N}$ yang tidak dimiliki oleh lemak dan karbohidrat. Molekul protein mengandung fosfor, belerang dan ada jenis protein yang mengandung unsur logam seperti besi dan tembaga (Winarno, 1992). Sebagai zat pembangun, protein merupakan bahan pembentuk jaringan-jaringan baru yang selalu terjadi dalam tubuh. Pada masa pertumbuhan proses pembentukan jaringan terjadi secara besar-besaran, pada masa kehamilan proteinlah yang membentuk jaringan janin dan pertumbuhan embrio. Protein juga mengganti-kan jaringan tubuh yang rusak dan yang perlu di rombak. Fungsi utama protein bagi tubuh ialah untuk membentuk jaringan baru dan mempertahankan jaringan yang telah ada (Winarno, 1992).

Peningkatan persentase pengetahuan peserta tentang kualitas susu segar meningkat hingga 87\% (Butir pertanyaan no. 7, Gambar 3). Susu segar adalah air susu hasil pemerahan yang tidak dikurangi atau ditambahkan bahan apapun yang diperoleh dari pemerahan sapi yang sehat. Susu merupakan bahan minuman yang sesuai untuk kebutuhan hewan dan manusia karena mengandung zat gizi dengan perbandingan yang optimal, mudah dicerna dan tidak ada sisa yang terbuang. Susu segar mudah sekali mengalami kerusakan karena cemaran mikroba. Dalam suhu ruang, susu hanya bertahan maksimal empat jam setelah pemerahan. Kerusakan juga bisa terjadi karena proses pemerahan tidak bersih dan wadah yang tercemar. Sehingga setelah susu diperah dari sapi perah, harus segera dilakukan penanganan dan proses pengolahan susu. Untuk memperpanjang daya simpannya, susu segar segera dipasteurisasi dan disimpan pada suhu dibawah $10^{\circ} \mathrm{C}$. Pada suhu tersebut mikroba pembusuk tidak dapat tumbuh dan berkembang. Terjadi peningkatan pengetahuan peserta tentang kualitas susu segar dan pengaruh proses pengolahan terhadap kualitas susu segar. Proses pengolahan akan memperpanjang umur simpan susu dan menjaga kesegaran serta kualitas susu. Beberapa proses pengolahan susu segar yang dapat dilakukan adalah proses pasteurisasi. Pada industri susu, susu segar ada yang diolah menjadi susu evaporasi, susu bubuk, susu kental manis susu sterilisasi dan susu fermentasi. Proses pengolahan susu akan memperpanjang umur simpan susu.

Berbagai jenis produk susu olahan dapat digunakan sebagai bahan baku untuk pengolahan produk minuman. Salah satu minuman yang diolah dengan menggunakan es krim adalah milkshake.

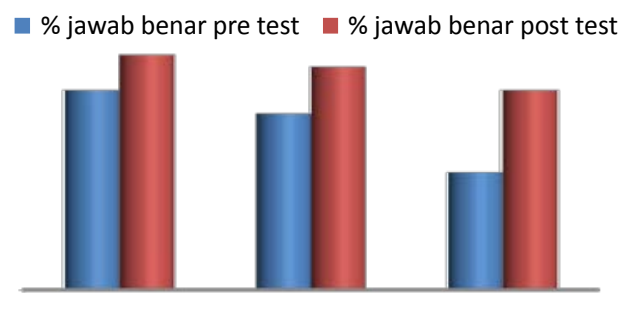

Gambar 3. Persentase Pengetahuan Kualitas Susu dan Pengaruh Proses pengolahan

Es krim adalah buih setengah beku yang mengandung lemak teremulsi dan udara. Sel-sel udara yang ada berperan untuk memberikan 
tekstur lembut pada es krim tersebut. Tanpa udara, emulsi beku tersebut akan menjadi terlalu dingin dan terlalu berlemak. Sebaliknya, jika kandungan udara dalam es krim terlalu banyak akan terasa lebih cair dan lebih hangat sehingga kurang enak. Lemak susu terlalu rendah, akan membuat es lebih besar dan teksturnya lebih kasar serta terasa lebih dingin. Untuk menjaga kualitas es krim agar tetap baik, maka es krim sebaiknya disimpan pada suhu beku $\left(<10^{\circ} \mathrm{C}\right)$. Terjadi peningkatan pengetahuan peserta tentang proses penyimpanan es krim dari 34.8\% menjadi $60.9 \%$.

Setelah pelatihan peserta dapat melakukan proses pengolahan es krim menjadi berbagai jenis milkshake, seperti milkshake susu kedelai, milkshake mangga, milkshake cokelat dan sebagainya. Peserta pelatihan dan anak balitanya sangat menyukai produk olahan es krim tersebut.

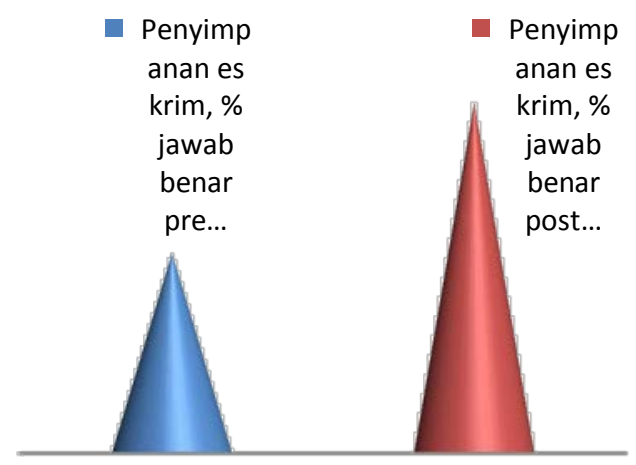

Gambar 4. Persentase Pengetahuan Kualitas Susu dan Pengaruh Proses pengolahan

\section{KESIMPULAN DAN SARAN}

Setelah dilaksanakan kegiatan pengabdian pada masyarakat ini kader Posyandu sebagai salah satu sasaran awal penerapan IPTEK di Kelurahan Duren Sawit, Kecamatan Duren Sawit dapat melakukan pembuatan es krim sehat bagi balita dalam bentuk minuman milkshake susu kedelai, milkshake mangga, milkshake cokelat. Sebagai khalayak sasaran yang strategis kader Posyandu diharapkan dapat menyebarluaskan pengetahuan dan keterampilan mereka pada masyarakat sekitarnya. Kader posyandu dan masyarakat di sekitarnya dapat membuat milkshake sebagai minuman sehat dan bergizi bagi balita, serta memanfaatkan peluang usaha untuk menggantikan produk minuman kurang sehat yang banyak beredar dimasyarakat.

\section{DAFTAR PUSTAKA}

Marshall, R. T., and W. S. Arbuckle. 1996. Pages 59, 151-185, 263-267, 319 in Ice Cream. 5th ed. International Thomson Publ., New York.

Marshall, R.T., H.D Goff and R.W. Hartel.2003. Ice Cream. Sixth Edition. Kluwer Academic. Planum Publisher. New York.

McBride, R.L and H.J.H..1990. Psychological Basis of Sensory Evaluation. Elsiver Science Publisher Ltd. New York

Muse, MR., dan W. Kartel, 2004. Ice Cream Structure Elements that Affect Melting Rate and Hardness. ADSA. J.Dairy Sci. 87:1-10. Diakses 18 September 2

Winarno, F. G. 1992. Kimia Pangan dan Gizi. Gramedia. Jakarta. 